\title{
Muhasebe meslek mensuplarının büyük veri analitiği teknolojisi direncine yönelik bir araştırma
}

\section{A study on the big data analytics technology resistance of accountants}

\author{
Mehmet Yücenurşen ${ }^{1}$
}

${ }^{1}$ Doç. Dr., Aksaray Üniversitesi, Aksaray, Türkiye, yucenursen@hotmail.com

ORCID: 0000-0002-6327-0169

Başvuru/Submitted: 1/07/2021

Revizyon/Revised: 6/08/2021

Kabul/Accepted: 24/08/2021

Yayın/Online Published: 25/09/2021

Öz

Bu çalışmanın amacı, Statüko Yanlılı̆̆ı (Status Quo Bias) Teorisi çerçevesinde muhasebe meslek mensuplarının yeni veri analitiği teknolojisi direncine neden olan faktörleri incelemektir. Araştırmada, Aksaray ilinde aktif olarak çalışan Serbest Muhasebeci Mali Müşavirler (SMMM) anakütle olarak tespit edilmiş ve 100 adet SMMM'ye bir anket uygulanmıştır. Toplanan verilere; tanımlayıcı istatistikler ile açımlayıcı faktör analizi, keşfedici faktör analizi ve yol analizleri uygulanmıştır. Elde edilen bulgular; algılanan değer, değişim maliyeti ve meslektaş görüşlerinin değişime direnç üzerinde etkili olduğunu göstermektedir.

Anahtar Kelimeler: Veri Analitiği, Değişime Direnç, Statüko Yanlılığı Teorisi

Jel Kodları: M41, M49

\begin{abstract}
This study examines the factors that cause new data analytics technology resistance of professional accountants within the Status Quo Bias Theory framework. In the study, Certified Public Accountants (CPA) operating in Aksaray province were determined as the population, and a questionnaire was applied to 100 accounting professionals. In the analysis of the obtained data, descriptive statistics, exploratory factor analysis and path analysis were performed. Obtained findings show that perceived value, switching costs, and colleague opinions effectively resist change.
\end{abstract}

Keywords: Data Analytics, Resistance to Change, Status Quo Bias Theory

Jel Codes: M41, M49

Atıf/Citation: Yücenurşen, M., Muhasebe meslek mensuplarının büyük veri analitiği teknolojisi direncine yönelik bir araştırma, bmij (2021) 9 (3): 1088-1103, doi:

https://doi.org/10.15295/bmij.v9i3.1882 


\section{Extended Abstract}

\section{A study on the big data analytics technology resistance of accountants}

\section{Literature}

The nature of the data analytics concept includes quick thinking, openness to explore new data paths and forms, analytical approaches, and innovative predictions (Tsai, Lai, Chao \& Vasilakos, 2015). In this context, Big Data requires advanced capabilities in data analytics because it consists of "structured, semi-structured and unstructured data types." (Aktan, 2018). In this case, the accounting profession; must have the concept of Big Data and data analytics and adapt to artificial intelligence and automation accordingly. However, achieving this requires a redefinition of the accounting profession, and it is generally seen that the members of the accounting profession are "resistance to this change" (Yardımcioğlu, Karahan \& Yörük, 2019).

Although it has become mandatory for professional accountants to benefit from data analytics, professional accountants seem to be resistant to possible changes and are content to wait, see and leave new technology to others (Richins, Stapleton, Stratopoulos \& Wong, 2017; Dzuranin, Jones \& Olvera, 2018). However, large accounting firms (Deloitte, Ernst \& Young, etc.) are unwilling to wait and invest heavily in new data analytics technology. In this context, the companies in question employ data analysts, data scientists, and technologists who are "savvy with change."

\section{Research subject}

The research subject has been determined as “Does the Status Quo Bias Theory explain the resistance of professional accountants to switch to non-Excel data analysis tools?"

\section{Research purpose and importance}

The primary purpose of this study is to determine the factors that cause new data analytics technology resistance of professional accountants.

\section{Contribution of the article to the literature}

In the Turkish literature, it is seen that there is no empirical study on the new data analytics technology resistance of professional accountants. For this reason, this study was carried out for accounting professionals.

\section{Design and method}

\section{Research type}

This study is designed as a descriptive study.

\section{Research problems}

The research problem is to identify the factors affecting the resistance of professional accountants to switch to non-Excel data analysis tools within the framework of Status Quo Bias Theory.

\section{Data collection method}

The primary data of this quantitatively designed study consisted of questionnaires applied to accountants and conducted using the face-to-face interview method.

\section{Quantitative/qualitative analysis}

In order to test the hypotheses developed in the research, Confirmatory Factor Analysis was carried out to understand the relationship between each expression and the relevant hidden structure. After confirmatory factor analysis, path analysis was performed with the AMOS package program to test the hypotheses.

\section{Research model}

The model of the research is presented below.

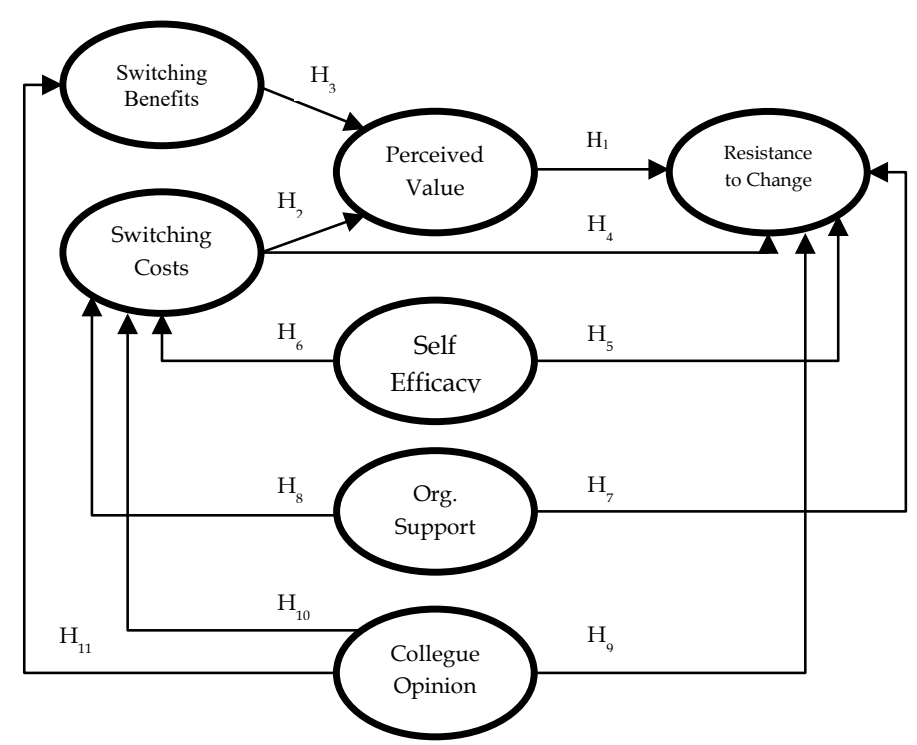

\section{Research hypotheses}

The hypotheses of the research are as follows. 
$\mathbf{H}_{1}$ : The perceived value of migrating to a new data analytics software is negatively correlated with resistance to change.

$\mathbf{H}_{2}$ : Switching costs are negatively correlated with an individual's perceived value for a new data analysis tool.

$\mathbf{H}_{3}$ : Switching benefits is positively correlated with an individual's perceived value for a new data analysis tool.

$\mathbf{H}_{4}$ : Switching costs are positively associated with resistance to change.

$\mathbf{H}_{5}$ : Self-efficacy is negatively associated with resistance to change.

H6: Self-efficacy is negatively associated with switching costs.

$\mathbf{H}_{7}$ : Organizational support is negatively associated with resistance to change.

$\mathbf{H}_{8}$ : Organizational support is negatively associated with switching costs.

H9: Colleague opinions are negatively related to resistance to change.

$\mathbf{H}_{10}$ : Colleague opinions are negatively related to the cost of change.

$\mathbf{H}_{11}$ : Colleague opinions are positively associated with change utility.

\section{Findings and discussion}

Findings as a result of analysis

As a result of CFA and path analyses, it is seen that the data fit the established model.

\section{Hypothesis test results}

The results of the hypothesis tests are shown below.

\begin{tabular}{|c|c|c|c|c|c|}
\hline Hypothesis & Endogenous Variable & Exogenous Variable & Standardized R.W. & P & Support Status \\
\hline $\mathrm{H}_{1}$ & Resistance to Change & Perceived Value &,- 279 &, 004 & Supported \\
\hline $\mathrm{H}_{2}$ & Perceived Value & Switching Costs &,- 088 &, 126 & Not Supported \\
\hline $\mathrm{H}_{3}$ & Perceived Value & Switching Benefits &, 858 &, 001 & Supported \\
\hline $\mathrm{H}_{4}$ & Resistance to Change & Switching Costs &, 765 &, 001 & Supported \\
\hline $\mathrm{H}_{5}$ & Resistance to Change & Self Efficacy &, 023 &, 826 & Not Supported \\
\hline $\mathrm{H}_{6}$ & Switching Costs & Self Efficacy &,- 010 &, 947 & Not Supported \\
\hline $\mathrm{H}_{7}$ & Resistance to Change & Organizational Support &,- 108 &, 286 & Not Supported \\
\hline $\mathrm{H}_{8}$ & Switching Costs & Organizational Support &,- 434 &, 001 & Supported \\
\hline $\mathrm{H}_{9}$ & Resistance to Change & Colleague Opinions &,- 259 &, 023 & Supported \\
\hline $\mathrm{H}_{10}$ & Switching Costs & Colleague Opinions &,- 241 &, 049 & Supported \\
\hline $\mathrm{H}_{11}$ & Switching Benefits & Colleague Opinions &, 753 &, 001 & Supported \\
\hline
\end{tabular}

\section{Discussing the findings with the literature}

It was observed that the perceived value in the basic model in the study affected the perception of resistance to change negatively and significantly $\left(\mathrm{H}_{1}\right)$. This finding is consistent with the findings obtained in previous studies (Kim \& Kankanhalli, 2009; Schmidt, Riley, \& Church, 2020; Shittu, Gambari \& Obielodan, 2016; Kim, 2011). In this context, it can be said that the value that professional accountants expect from a new data analytics software is high.

In the basic model, it was observed that the perceived value was not affected by the switching cost but was positively and significantly affected by the switching benefits $(\mathrm{H} 2, \mathrm{H} 3)$. According to the research findings, switching costs affects the perception of resistance to change positively and significantly $(\mathrm{H} 4)$. These findings are consistent with the findings obtained in previous studies (Setiaputri \& Kuntara, 2019; Kim, 2011; Fan, Chen, Wu \& Fang, 2015; Tong, Tan \& Teo, 2015).

In the basic model of the research, it was observed that the self-efficacy of the accounting professionals did not affect the perceptions of switching costs and resistance to change $\left(\mathrm{H}_{5}, \mathrm{H}_{6}\right)$. These findings are consistent with the findings obtained in previous studies (Schmidt, Riley, \& Church, 2020; Kim \& Kankanhalli, 2009).

It is seen that organizational support has no effect on resistance to change but has a negative and significant effect on the switching costs $\left(\mathrm{H}_{7}, \mathrm{H}_{8}\right)$. These findings are consistent with the findings obtained in previous studies (Schmidt, Riley, \& Church, 2020; Kim \& Kankanhalli, 2009). In this context, it can be said that professional accountants expect the discomfort they perceive during the transition to the new data analytics tool to be reduced with organizational support. It can be said that professional accountants have low self-efficacy and therefore need support in the transition process.

In the basic model, peer opinions have a negative and significant effect on the perceptions of resistance to change and switching costs $\left(\mathrm{H}_{9}, \mathrm{H}_{10}\right)$, while it has a positive and significant effect on the perception of switching benefits $\left(\mathrm{H}_{11}\right)$. These findings are consistent with the findings obtained in previous studies (Venkatesh \& Davis, 2000; William Lewis \& Sambamurthy, 2003; Schmidt, Riley \& Church, 2020; Kim \& Kankanhalli, 2009).

\section{Conclusion, recommendation and limitations}

\section{Results of the article}

The research findings show that professional accountants view their perceived value of new data analytics technology as a function of switching benefits. However, participants think that switching costs do not affect perceived value. However, switching costs have a strong and negative direct impact on resistance to migrating to a new data analytics technology. Furthermore, in research findings, determinations regarding the opinion of colleagues are essential. Accordingly, peer opinions significantly and positively affect the perception of switching benefits and reduce resistance to change.

Businesses aim to maintain an efficient and effective business model through the provision of financial data. However, with the rise of Big Data and new data analytics technologies, some organizational structures will transform. Understanding the critical role of data integrity throughout the collection and processing stages, designing the business model based on a more detailed 
understanding of information, enabling better use of new technologies for data analysis, the increasing importance of cost management and outsourcing, and cloud-based capabilities are mandatory to change for professional accountants.

\section{Suggestions based on results}

At the same time, the scale used in the research can be applied to the accounting professionals operating in different regions and provinces, and the differences can be evaluated. Carrying out such studies will help identify the factors that cause professional accountants to resist the transition to new data analytics technology and help professional accountants use tools appropriate to the age requirements. 


\section{Giriş}

Gelişen teknoloji, finansal işlemlerin muhasebeleştirilmesi sürecini de etkilemektedir. Muhasebe süreçleri, tamamen insan kaynaklı orijinal kayıtlardan muhasebe yazılımlarına ve günümüz bulut tabanlı sistemlere kadar zaman içinde değişim göstermiştir. Big Data (Büyük Veri), muhasebe süreçlerinin gerçekleştirme şeklini değiştirecek başka bir teknoloji paradigmasıdır.

Büyük Veri'nin varlığı, muhasebe meslek mensuplarının veri analitiği teknolojisini kullanarak yeni paradigmaya uygun hareket etmelerini zorunlu kılmaktadır. Aksi takdirde muhasebe mesleği, 'unutulmuş meslekler' arasına girememekten kaçamayacaktır. Günümüzde muhasebe şirketlerinin veri analizi yeteneklerine bağlı işgücüne yatırım yapmakta olduğu görülmektedir. Ancak muhasebe meslek mensuplarının, muhasebe şirketlerinin 'muhasebeci'ler yerine veri bilimcileri işe almasına rağmen yeni veri analitiği teknolojisi araçlarına geçmeye direndiği görülmektedir.

Türkçe literatürde, muhasebe meslek mensuplarının yeni veri analitiği teknolojisi direncine yönelik ampirik bir çalışma bulunmadığı görülmektedir. Bu nedenden dolayı, muhasebe meslek mensuplarına yönelik olarak bu çalışma gerçekleştirilmiştir.

Çalışmada öncelikle yeni veri analitiği ve muhasebe meslek mensuplarını yeni veri analitiği araçlarını kullanmaya zorlayan nedenler ile ilgili kavramsal çerçeve açıklanmaya çalışılmış ve yöntem kısmında ise Aksaray ilinde aktif olarak çalışan 100 adet Serbest Muhasebeci Mali Müşavirden elde edilen anket verileri üzerinden açımlayıcı ve doğrulayıcı faktör analizleri ile yol analizi gerçekleştirilmiştir. Analiz sonucunda elde edilen bulgular yorumlanmış ve yeni veri analitiği teknolojisine direnç algısını etkileyen faktörler ve aralarındaki ilişki açıklanmaya çalışılmıştır.

\section{Kavramsal çerçeve}

Veri analitiği teknolojisi, muhasebe mesleğinin karşı karşıya olduğu en önemli sorunlardan biri haline gelmiştir. Hızla gelişen teknoloji, muhasebe meslek mensupları için bir dönüşümü zorunlu kılmaktadır. Muhasebe meslek mensupları Endüstri 4.0 ile hayata geçen Büyük Veri'ye, veri analitiğine ve dolayısıyla yapay zekanın ve otomasyonun yeni dünyasına uyum sağlamazlarsa muhasebe mesleği, "demode" olmaktan kaçamayacaktır (Schmidt, Church ve Riley, 2020).

İşletmeler, muhasebe verilerinin sunduğu benzersiz iş imkanlarını kontrol etmek için daha hızlı sonuç verebilen ve kullanıcı dostu araçlara ihtiyaç duymaktadırlar. Ancak muhasebe verilerini kullanmadan önce veri kalitesi/büyüklüğü/karmaşıklığıyla mücadele etmek ve istenen sonuçlara ulaşmak her zaman mümkün olmamaktadır. Bu noktada veri analitiğine ihtiyaç duyulmaktadır. Veri analitiği, faydalı bilgiyi bulmak ve iletmek, sonuçlar önermek ve karar vermeyi desteklemek için veriyi inceleme, temizleme, dönüştürme ve modelleme sürecidir (Cao, Chychyla ve Stewart, 2015).

Frey ve Osborne (2013), muhasebe ve denetim faaliyetlerinin otomatik hale gelme olasilığının \%94 olacağını tahmin etmektedir. Büyük Veri'ye uygulanan veri analitiği teknikleri, muhasebe meslek mensupları tarafından gerçekleştirilen iş ve işlemlerin çoğunun yerini alma potansiyeline sahiptir (Vasarhelyi, Kogan ve Tuttle, 2015). Fatura işlenmesi, alacak tahsili gibi iş ve işlemler, halihazırda otomatik hale getirilmiştir. Yakın gelecekte, muhasebe meslek mensupları tarafından halihazırda gerçekleştirilen finansal tablolar analizi, denetim gibi daha karmaşık iş ve işlemler, yapay zekâ ile otomatik olarak gerçekleştirilebilir (Frey ve Osborne, 2013).

Veri analitiği, ham verileri analize tabi tutarak sonuç çıkartma faaliyetleri olarak tanımlanabilir. Bu bağlamda veri analitiği, verilerden değer elde etmek ve kararları desteklemek için yeni ve gelişmiş araçların kullanımını içerir (Zakir, Seymour ve Berg, 2015). Bu araçlara örnek olarak; önyükleme, ridge regresyonu, karar ağaçları, yapay sinir ağları, rastgele ormanlar algoritması, kümeleme analizi, makine öğrenmesi, destek vektör makineleri, Bayes ağları vb. verilebilir (Kılıç, 2019). Muhasebe ve finans alanında genellikle regresyon, karar ağaçları, yapay sinir ağları kullanılmaktadır ki "bu tekniklerin ve teknolojilerin, işletmelerde finansal kriz tahminlerinin en doğru şekilde yapılabilmesine katkı să̆ladığı görülmüştür" (Kılıç, 2019). Söz konusu bu araçlar, "Excel" yazılımının üstündedir ve veriler "Büyük Veri" olduğu için gereklilik arz eder.

Büyük Veri "yüksek hacimli, yüksek hızlı ve/veya yüksek çeşitlilikteki verileri tanımlamak için kullanılan bir terimdir; verileri toplamak, depolamak ve analiz etmek için yeni teknolojiler ve teknikler gerektirir ve karar vermeyi geliştirmek, içgörü ve keşif sağlamak ve süreçleri desteklemek ve optimize etmek için kullanılır." (Rajaraman, 2016). Bu tanım ışığında Büyük Veri; verilerin büyüklüğünü, çeşitliliğini, değişim oranını ve ne ifade ettiğine dair fikir edinmek için verilerin analiz edilmesi gerektiğini vurgular (Warren Jr., Moffitt ve Byrnes, 2015). Aynı zamanda, analiz için yeni araçlara ihtiyaç vardır. 
Veri analitiği kavramının doğasında hızlı düşünmek, yeni veri yolları ve biçimlerini keşfetmeye açıklık, analitik yaklaşımlar ve yenilikçi tahminler vardır (Tsai, Lai, Chao ve Vasilakos, 2015). Bu bağlamda Büyük Veri, "yapısal, yarı yapısal ve yapısal olmayan veri türlerinden oluştuğu için veri analitiğinde ileri kabiliyetlere gereksinim duyulmaktadır." (Aktan, 2018). Bu durumda muhasebe mesleği; Büyük Veri kavramına, veri analitiğine sahip olmalı ve buna bağlı olarak yapay zekâ ve otomasyona uyum sağlamalıdır. Bunu gerçekleştirmek, muhasebe mesleğinin yeniden tanımlanmasını gerektirir ki genel olarak muhasebe meslek mensuplarının bu "değişime direndiği" görülmektedir (Yardımcıŏ̆lu, Karahan ve Yörük, 2019).

Muhasebe meslek mensuplarının veri analitiğinden yararlanmaları zorunlu hale gelmiş olsa da muhasebe meslek mensupları olası değişikliklere karşı direnç göstermekte ve beklemek, görmek ve yeni teknolojiyi başkalarına bırakmaktan memnun görünmektedir (Richins, Stapleton, Stratopoulos ve Wong, 2017; Dzuranin, Jones ve Olvera, 2018). Ancak büyük muhasebe şirketleri (Deloitte, Ernst \& Young vb.) beklemekle yetinmemekte ve yeni veri analitiği teknolojisine yoğun bir şekilde yatırım yapmaktadır. Bu bağlamda söz konusu şirketler; “değişime ayak uyduran” veri analistlerini, veri bilimcilerini ve teknoloji uzmanlarını istihdam etmektedir.

Muhasebe alanında yer alan paydaşlar (akademisyenler, meslek mensupları vb.), muhasebe meslek mensuplarının bir veri analitiğini benimsemesi ve ona uyum sağlaması gerektiğini veya yok olma tehlikesiyle karşı karşıya kalacağını belirtmektedirler (Dursun, Ektik ve Tutcu, 2019; Beder, 2021). Son yıllarda yaşanan teknolojik gelişmelerin muhasebe mesleği üzerinde etkisi olsa da veri analitiğinin getirdiği değişikliklerin hızı ve büyüklüğü tartışmasız en etkili olanlardan biridir (Agyekum ve Singh, 2018). Bu bağlamda büyük muhasebe şirketleri ve diğer şirketler, veri analitiği araçlarını ve veri analitiği konusunda oldukça yetenekli iş gücüne yapılan önemli yatırımları içeren önemli kaynaklar tahsis etmişlerdir.

"Geleceğin muhasebecisi; robotlarla çalşabilen, dijital gelişmelere ayak uydurabilen ve teknolojik gelişmeler karşısında veri analizini başarıla yapabilen, liderlik özellikleri gelişmiş, verileri okuyabilen ve bu konuda şirketlere danışmanlık yapan kişiler olacaktır. Muhasebenin çalışma alan değiş̧eceğinden meslek mensuplarının yeni yeterlilikler kazanması gerekecektir. Geleceğin muhasebecisi, gelecekteki teknolojik değişimleri kucaklayabilen, sistemin bir parçası olabilen kişiler olacaktır." (Akdoğan ve Akdoğan, 2018).

\section{Literatür taraması}

Dzuranin, Jones ve Olvera (2018) çalışmalarında, üniversitelerin veri analitiği ve bilgi teknolojisi becerileriyle ilişkili içerik ve öğrenme hedeflerini gerçekleştirebilmeleri için odaklanmış bir yaklaşım, entegre bir yaklaşım ve hibrit bir yaklaşım olmak üzere 3 farklı yaklaşım önerisinde bulunmuşlar ve hangi yaklaşımın tercih edileceğini belirlemek için Muhasebe Fakültesi öğretim elemanlarına anket uygulamışlardır. Araştırma sonuçlarına göre hibrit bir yaklaşım benimsenmiştir.

Cainas, Tietz ve Miller-Nobles (2021) ise çalışmalarında, özel bir sigorta şirketi tarafından finansal muhasebe ve yönetim muhasebesine ilişkin olarak sunulan; veri kontrolü, veri görselleştirme gibi işlemler içeren bir veri analitiği vaka çalışmasına katılan $2.700^{\prime}$ ün üzerinde öğrencinin vaka çalışması sırasında kullandıkları Excel, Power BI, Tableau yazılımlarına ilişkin yetkinliklerini incelemişlerdir. Araştırma sonuçlarına göre; çok az öğrencinin Power BI ve Tableau yazılımlarına aşina olmasına rağmen öğrencilerin veri analitiği becerilerinin geliştiği görülmüş̧tür.

Ballou, Heitger ve Stoel (2018), muhasebe müfredatı içinde ihtiyaç duyulan bilgi, beceri ve yetenekleri araştırarak veriye dayalı karar verme süreçlerinin müfredat üzerindeki etkisini incelemeye yönelik bir çalışma gerçekleştirmişlerdir. Özel sektör çalışanları ve öğretim elemanları üzerinde yürütülen araştırmada; özel sektörde çalışanlarının öğretim elemanlarına göre muhasebe müfredatı içinde ihtiyaç duyulan bilgi, beceri ve yeteneklerine eşit olarak odaklandığı tespit edilmiştir. Çalışmada, söz konusu bilgi, beceri ve yeteneklerin muhasebe müfredatına daha kapsamlı bir şekilde entegre edilmesi için öneriler sunulmuştur.

Özer, Özcan ve Aktaş (2010), yürüttükleri çalışmalarında muhasebecilerin bilgi teknolojisi kullanımına yönelik davranışlarını Teknoloji Kabul Modeli çerçevesinde belirlemeyi amaçlamışlardır. 456 muhasebe meslek mensubundan anket yoluyla elde edilen verileri analizi sonucunda; algilanan fayda ve algılanan kullanım kolaylığının bilgi teknolojisi kullanımına yönelik tutumu üzerinde olumlu etkiye sahip olduğu tespit edilmiştir.

Schneider, Dai, Janvrin, Ajayi ve Raschke (2015) ise çalışmalarında, mevcut veri analitiği kullanımını belirlemeyi ve veri analizinin muhasebe ortamını nasıl etkilediğini incelemeyi amaçlamışlardır. Çalışma sonucunda, veri analitiğinin iş kullanımının muhasebe alanında hızla arttığını, muhasebe bilgilerini içeren birçok yeni sisteme benzer şekilde, veri analitiğinin özellikle karar vericilere çıkarım, tahmin ve 
güvence sağlayan işlemler olmak üzere görev süreçlerini temelden değiştirdiğini, bu nedenle, muhasebe araştırmacıları ve uygulayıcılarının, çalışmalarında veri analitiğini ve bunun muhasebe uygulaması üzerindeki etkisini dikkate almaları gerekliliği vurgulanmıştır.

K1lı̧ (2019), çalışmasında büyük veri analiz tekniklerinin denetim alanında hangi alanlarda ve ne ölçüde kullanıldığını değerlendirmeyi amaçlamıştır. Çalışma sonucunda, muhasebe ve finans alanlarına göre denetim alanının büyük veri tekniklerinin ve teknolojilerinin kullanımında biraz daha geri kaldığı belirtilmektedir.

Cao, Chychyla ve Stewart (2015) ise çalışmalarında Büyük Veri analitiğinin finansal tablo denetimlerinin verimliliğini ve etkinliğini artırabileceğini varsaymaktadır. Ayrıca çalışmalarında, diğer alanlarda uygulanan Büyük Veri analitiğinin denetimde nasıl uygulanabileceğini açılamaktadırlar.

Literatür incelendiğinde, veri analitiğinin müfredata entegrasyonu, veri analitiğinin muhasebe denetimi ve yönetim muhasebesine etkileri, veri analitiğinin muhasebe mesleğinin kaderi hakkında çıkarımlar, veri analitiğinin uygulama alanları ve etkinliği gibi konularda çalışmalar gerçekleştirildiği görülmektedir.

\section{Araştırmanın metodolojisi}

\section{Araştırmanın amacı, modeli ve hipotezleri}

$\mathrm{Bu}$ araştırma, muhasebe meslek mensuplarının yeni veri analitiği teknolojisi direncine yönelik olarak gerçekleştirilmiştir. Bu bağlamda araştırma, muhasebe meslek mensuplarının yeni veri analitiği teknolojisi direncine etki eden unsurları belirlemek açısından önem arz etmektedir.

Araştırmada, Schmidt, Riley ve Church (2020) tarafından Statüko Yanlılığ1 (Status Quo Bias) Teorisi temelinde, Teknoloji Kabul Modeli (TAM) ve Planlı Davranış Teorisi (TPB) entegrasyonu ile geliştirilen model kullanılmıştır. Bu bağlamda araştırma problemi; "Statüko Önyargı Teorisi, muhasebe meslek mensuplarının Excel dışı veri analizi araçlarına geçme direncini açıklıyor mu?" olarak belirlenmiştir. Bu bağlamda araştırmanın modeli Şekil 1'de sunulmaktadır.

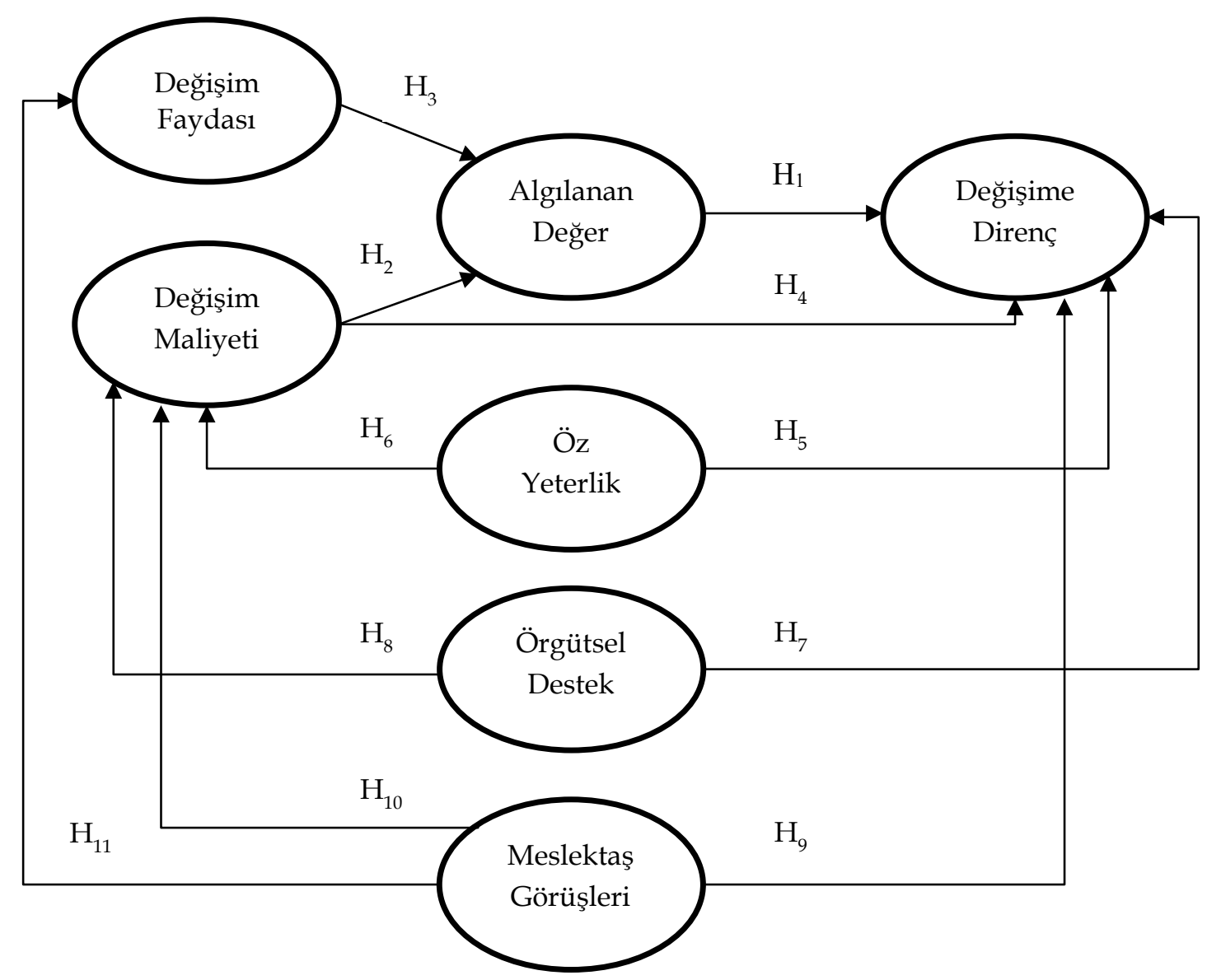

Şekil 1: Araştırmanın Modeli

Kaynak: Schmidt, Riley ve Church'ten (2020) uyarlanmıştır.

Rasyonel karar verme ilkeleri çerçevesinde, herhangi bir seçimin algılanan değeri, o seçimin net faydasının bir fonksiyonudur (Kahneman, 2015; Kahneman ve Tversky, 1979). Bireyler genellikle kendi 
çıkarları doğrultusunda hareket ettikleri için, seçimlerine ilişkin net faydaları değerlendirerek ve ardından yeni araca direnerek veya kabul ederek değeri en üst düzeye çıarmayı seçerler. Aynı zamanda algılanan değeri, değişim faydası (bir meslek mensubunun yeni veri analitiği aracına geçerken algıladığı fayda) ve değişim maliyetleri (bir meslek mensubunun yeni veri analitiği aracına geçerken algıladığı rahatsızlık) etkilemektedir (Kim ve Kankanhalli, 2009).

$\mathbf{H}_{1}$ : Yeni bir veri analitiği yazılımına geçmenin algılanan değeri, değişime direnç ile negatif yönde ilişkilidir.

$\mathbf{H}_{2}$ : Değişim maliyetleri, bir bireyin yeni bir veri analizi aracına ilişkin algılanan değeri ile negatif yönde ilişkilidir.

$\mathbf{H}_{3}$ : Değişim faydası, bir bireyin yeni bir veri analizi aracına ilişkin algılanan değeri ile pozitif yönde ilişkilidir.

Değişim maliyetleri, bireylerin kayıpları önleme motivasyonları nedeniyle değişime karşı direnişini ifade etmektedir (Kahneman, 2015). Bu bağlamda değişim maliyeti, bir bireyin değişime direnci ile doğrudan ilişkilidir.

$\mathbf{H}_{4}$ : Değişim maliyeti, değişime direnç ile pozitif yönde ilişkilidir.

Statüko Yanlılığı kavramı uyarınca, düşük öz yeterlik düzeylerine sahip bireylerin, değişim durumunda tehdit altında hissetme ve yeni duruma hakim olmak için istenen gerekliliklerden korkma olasılıkları daha yüksektir (Kim ve Kankanhalli, 2009). Bu bağlamda, öz yeterliliğin yeni bir veri analitiği aracına geçiş direnci ile ters bir ilişkiye sahip olacağı beklenen bir durumdur (Compeau, Higgins ve Huff, 1999). Aynı zamanda öz yeterlik, bir bireyin değişim maliyetlerine ilişkin değerlendirmesini de etkileyebilir.

$\mathbf{H}_{5}$ : Öz yeterlik, değişime direnç ile negatif yönde ilişkilidir.

$\mathbf{H}_{6}$ : Öz yeterlik, değişim maliyetleri ile negatif yönde ilişkilidir.

Dış etkiler, bir kullanıcının yeni bir veri analitiği aracına geçmeye karşı direncini de etkileyebilir. Kim ve Kankanhalli (2009) değişime yönelik örgütsel desteği, kullanıcıların veri analitiği ile ilgili değişime adaptasyonunu kolaylaştırmak için kuruluş tarafından destek olarak tanımlamaktadır. Şirket yönetimi veya meslek odaları, değişim için destek vererek, kullanıcıları yeni bir veri analitiği aracına karşı daha olumlu bir tutum sergilemeye teşvik edebilir (Eisenberger, Huntington, Hutchison ve Sowa, 1986; Hutchison, 1997; Pardo del Val ve Martinez Fuentes, 2003). Bu durum, bir kullanıcının değişime direncini doğrudan azaltacaktır.

$\mathbf{H}_{7}$ : Örgütsel destek, değişime direnç ile negatif yönde ilişkilidir.

$\mathbf{H}_{8}$ : Örgütsel destek, değişim maliyetleri ile negatif yönde ilişkilidir.

Bireyler çalışmak, başarılı olmak ve başarının karşılığı olarak ekonomik ve sosyal getiriler elde etmeyi arzu ederler (Pehlivanlı, 2020: 67). Bireyler gerçekleştirdikleri eylemler için yakın çevrelerinden onay ararlar ve meslektaşlarından olumsuz tepkilerden kaçınırlar, bu durum da uyum eğilimine neden olur (Ajzen, 2002). Bu bağlamda, yeni bir veri analitiği yazılımına geçmeye direncin, meslektaşların yeni veri analitiği aracına ilişkin görüşlerinden doğrudan etkilenmesi beklenmektedir. Meslektaşlar, yeni bir veri analitiği aracına ilişkin bir değişikliğe yönelik olumlu bir fikir beyan ederlerse, değişim maliyeti etkilenebilir.

H9: Meslektaş görüşleri, değişime direnç ile negatif yönde ilişkilidir.

$\mathbf{H}_{10}$ : Meslektaş görüşleri, değişim maliyeti ile negatif yönde ilişkilidir.

$\mathbf{H}_{11}$ : Meslektaş görüşleri, değişim faydası ile pozitif yönde ilişkilidir.

\section{Araştırmanın örneklem seçimi, veri toplama süreci ve analiz yöntemleri}

Araştırmada, araştırma modeli çerçevesinde ampirik bir değerlendirme gerçekleştirmek için kuramsal bağlama uygun katılımcılardan veri toplanması amaçlanmıştır. Bu paralelde, Aksaray ilinde faaliyet göstermekte olan Serbest Muhasebeci Mali Müşavirler (SMMM) ana kütle olarak tespit edilmiştir. Aksaray SMMM odasindan elde edilen bilgilere göre, Aksaray'da odaya kayıtlı bulunan toplam 213 SMMM bulunmaktadır ancak söz konusu SMMM'lerin 133 tanesi aktif olarak faaliyet göstermektedir.

Tespit edilen ana kütleden \%95 güven aralığında ve \%5 hata payı ile örneklem büyüklüğü asgari 99 olarak belirlenmiştir (Saunders, Lewis ve Thornhill, 2007: 212). Araştırma nicel olarak tasarlanmış olup birincil verileri SMMM'lerden anket yöntemi ile toplanmıştır. Verilerin toplanmasında basit tesadüfi yöntem benimsenmiştir. 
Katılımcilardan toplanan anket formları incelemeye tabi tutulmuştur. 5 adet anket hatalı ve eksik veri giriş nedeniyle analiz dışı bırakılmıştır ve 100 adet anketin analize uygun olduğu tespit edilmiştir.

Araştırma kapsamında hazırlanan anket formu iki bölümden meydana gelmektedir. Anket formunun birinci bölümü katılımcılar ait demografik bilgiler; ikinci bölümü̈ ise Schmidt, Riley ve Church (2020) tarafından geliştirilen ölçek kapsamındaki ifadelerden meydana gelmektedir. Ankette mevcut olan bütün değişkenler için 5'li Likert tipi ölçek tercih edilmiştir.

Ölçek maddeleri 'algılanan değer' (1., 2., 3. ifadeler), 'değişim faydası' (4., 5., 6., 7. ifadeler), 'değişim maliyeti' (8., 9., 10., 11. ifadeler), 'değişime direnç' (12., 13., 14., 15. ifadeler), 'meslektaş görüşleri' (16., 17., 18. ifadeler), 'öz yeterlik' (19., 20., 21. ifadeler) ve 'örgütsel destek' (22., 23., 24. ifadeler) boyutlarıyla değerlendirilmeye alınmıştır.

Araştırmada ölçekten toplanan verilerin istatistiki analizini gerçekleştirmek için SPSS ve AMOS paket programları tercih edilmiştir. Ölçeğin iç tutarlılığını ölçmek için Cronbach Alfa katsayısı belirlenmiştir. Araştırmada kullanılan ölçeğin yapı geçerliliğini belirlemek için açımlayıcı ve doğrulayıcı faktör analizi uygulanmıştır. Hipotez testleri için yol analizi kullanılmıştır.

\section{Bulgu ve analizler}

\section{Araştırma örneklemine ilişkin bulgu ve değerlendirmeler}

Araştırma kapsamında katılımcılara ilişkin sosyo-demografik özellikler Tablo 1'de gösterilmiştir.

Tablo 1: Katılımcılara İlişkin Sosyo-Demografik Özellikler

\begin{tabular}{|c|c|c|c|c|c|c|c|}
\hline Değişken & Kategori & Frekans & Yüzde & Değişken & Kategori & Frekans & Yüzde \\
\hline \multirow{2}{*}{ Cinsiyet } & Erkek & 74 & 74 & \multirow{4}{*}{$\begin{array}{l}\text { Mesleki } \\
\text { Tecrübe }\end{array}$} & $1-5$ y1l & 21 & 21 \\
\hline & Kadın & 26 & 26 & & 6-10 y1l & 16 & 16 \\
\hline \multirow{4}{*}{ Yaş } & $18-25$ & 7 & 7 & & $11-15$ yıl & 27 & 27 \\
\hline & $26-35$ & 33 & 33 & & 16 ve üzeri & 36 & 36 \\
\hline & $36-45$ & 36 & 36 & \multirow{6}{*}{$\begin{array}{c}\text { Kullanılan } \\
\text { Muhasebe } \\
\text { Yazılımı }\end{array}$} & Zirve & 54 & 54 \\
\hline & 45 ve üzeri & 24 & 24 & & Eta & 20 & 20 \\
\hline \multirow{4}{*}{ Eğitim Durumu } & Lise & 12 & 12 & & Logo & 11 & 11 \\
\hline & Önlisans & 23 & 23 & & Luca & 7 & 7 \\
\hline & Lisans & 48 & 48 & & Mikro & 6 & 6 \\
\hline & Lisansüstü & 17 & 17 & & Diğer & 2 & 2 \\
\hline
\end{tabular}

Kaynak: Yazar tarafından üretilmiştir.

Tablo 1 incelendiğinde katılımcıların \%74'ünün erkek ve \%26'sının kadın olduğu belirlenmiştir. Aynı zamanda katılımcıların \%36'sının 36-45 yaş aralığında olduğu ve \%48'inin lisans düzeyinde eğitim aldığı belirlenmiştir. Katılımcıların büyük bir çoğunluğunun (\%54) "Zirve" muhasebe yazılımını tercih ettiği görülmektedir.

Tablo 2: Araştırmada Kullanılan Ölçeğe İlişkin Tanımlayıcı İstatistikler

\begin{tabular}{|c|c|c|c|c|c|}
\hline Boyutlar & Sorular & Ortalama & Standart Sapma & Çarpıklık & Basıklık \\
\hline \multirow{3}{*}{ Algılanan Değer } & ALG1 & \multirow{3}{*}{2,64} & \multirow{3}{*}{1,34980} & \multirow{3}{*}{,393 } & \multirow{3}{*}{$-1,158$} \\
\hline & ALG2 & & & & \\
\hline & ALG3 & & & & \\
\hline \multirow{4}{*}{ Değişim Faydası } & DEF4 & \multirow{4}{*}{2,76} & \multirow{4}{*}{1,36275} & \multirow{4}{*}{,257 } & \multirow{4}{*}{$-1,320$} \\
\hline & DEF5 & & & & \\
\hline & DEF6 & & & & \\
\hline & DEF7 & & & & \\
\hline \multirow{4}{*}{ Değişim Maliyeti } & DEM8 & \multirow{4}{*}{2,9175} & \multirow{4}{*}{1,05053} & \multirow{4}{*}{ 201 } & \multirow{4}{*}{,- 790} \\
\hline & DEM9 & & & & \\
\hline & DEM10 & & & & \\
\hline & DEM11 & & & & \\
\hline \multirow{4}{*}{ Değişime Direnç } & DED12 & \multirow{4}{*}{2,49} & \multirow{4}{*}{1,15137} & \multirow{4}{*}{,742 } & \multirow{4}{*}{,- 091} \\
\hline & DED13 & & & & \\
\hline & DED14 & & & & \\
\hline & DED15 & & & & \\
\hline \multirow{3}{*}{ Meslektaş Görüşleri } & MEG16 & \multirow{3}{*}{2,4867} & \multirow{3}{*}{1,24939} & \multirow{3}{*}{,542 } & \multirow{3}{*}{,- 848} \\
\hline & MEG17 & & & & \\
\hline & MEG18 & & & & \\
\hline \multirow{3}{*}{ Öz Yeterlik } & OZY19 & \multirow{3}{*}{2,9767} & \multirow{3}{*}{1,34110} & \multirow{3}{*}{,- 067} & \multirow{3}{*}{$-1,312$} \\
\hline & OZY20 & & & & \\
\hline & OZY21 & & & & \\
\hline \multirow{3}{*}{ Örgütsel Destek } & ORD22 & \multirow{3}{*}{2,2233} & \multirow{3}{*}{1,35094} & \multirow{3}{*}{877} & \\
\hline & ORD23 & & & &,- 533 \\
\hline & ORD24 & & & & \\
\hline
\end{tabular}

Kaynak: Yazar tarafından üretilmiştir. 
Tablo 2'ye göre, çarpıklık ve basıklık değerleri +/- 2 sınırları arasındadır. Söz konusu bu durum, ölçeğin normal dağılım varsayımını sağladığını göstermektedir. Veriler normal dağılım ölçütlerini sağladığından değişkenler arasındaki ilişkinin yönü ve gücünü belirlemede Pearson Korelasyon analizinden yararlanılmıştır. Bu bağlamda, değişkenler arası ilişki Tablo 3'te sunulmuştur.

Tablo 3: Değişkenler Arasındaki İlişki

\begin{tabular}{|c|c|c|c|c|c|c|c|c|c|}
\hline Faktörler & Mean & $\begin{array}{c}\text { Standart } \\
\text { Sapma }\end{array}$ & $\begin{array}{l}\text { Algılanan } \\
\text { Değer }\end{array}$ & $\begin{array}{l}\text { Değişim } \\
\text { Faydası }\end{array}$ & $\begin{array}{l}\text { Değisiim } \\
\text { Maliyeti }\end{array}$ & $\begin{array}{c}\text { Değişime } \\
\text { Direnç }\end{array}$ & $\begin{array}{l}\text { Meslektaş } \\
\text { Görüşleri }\end{array}$ & $\begin{array}{c}\text { Öz } \\
\text { Yeterlik }\end{array}$ & $\begin{array}{c}\text { Örgütsel } \\
\text { Destek }\end{array}$ \\
\hline $\begin{array}{c}\text { Algılanan } \\
\text { Değer }\end{array}$ & 2,6400 & 1,34980 & 1 & & & & & & \\
\hline $\begin{array}{c}\text { Değişim } \\
\text { Faydası }\end{array}$ & 2,7650 & 1,36275 &, $807^{* *}$ & 1 & & & & & \\
\hline $\begin{array}{l}\text { Değişim } \\
\text { Maliyeti }\end{array}$ & 2,9175 & 1,05053 & 117 & ,205* & 1 & & & & \\
\hline $\begin{array}{l}\text { Değişime } \\
\text { Direnç }\end{array}$ & 2,4900 & 1,15137 &,- 068 & ,082 & $686^{* *}$ & 1 & & & \\
\hline $\begin{array}{l}\text { Meslektaş } \\
\text { Görüşleri }\end{array}$ & 2,4867 & 1,24939 &, $729 * *$ &, $749^{* *}$ & 126 & ,095 & 1 & & \\
\hline $\begin{array}{c}\text { Öz } \\
\text { Yeterlik }\end{array}$ & 2,9767 & 1,34110 &, $584^{* *}$ &, $512^{* *}$ & 178 & ,085 &, $690 * *$ & 1 & \\
\hline $\begin{array}{c}\text { Örgütsel } \\
\text { Destek }\end{array}$ & 2,2233 & 1,35094 & $390 * *$ &, $396^{* *}$ & ,215* & 177 &, $575^{* *}$ &, $554^{* *}$ & 1 \\
\hline
\end{tabular}

Tablo 3'teki bulgularda muhasebe meslek mensuplarının örgütsel destek ölçeğinde genel anlamda "katılmıorum" (ort. =2,2233) tercihini benimsediği; değişim faydası düzeyinin görece düşük (ort. = 2,7650) olduğu, değişim maliyeti algısının ise değişim faydasına kıyasla biraz daha yüksek (ort. $=2,9175$ ) olduğu görülmektedir. Aynı zamanda katılımcıların öz yeterlik düzeyinin diğer değişkenlerden daha yüksek (ort. =2,9767) olduğu söylenebilir.

Tablo 3'te yer alan değişkenler arası ilişkiler incelendiğinde; katılımcıların değiş̧im faydası algısı ile algılanan değer düzeyleri arasında güçlü ve doğru yönde $(r=, 807)$ bir ilişki bulunmaktadır. Yine meslektaşların görüşleri ile algılanan değer arasında güçlü ve doğru yönde $(r=, 729)$ bir ilişki vardır. Öz yeterlik ile algılanan değer ve değişim faydası arasında orta düzeyde ve olumlu yönde $(r=, 584, r=, 512)$ bir ilişki mevcuttur.

Tablo 4: Araştırmada Kullanılan Ölçeğe İlişkin Açımlayıcı Faktör Analizi Sonuçları

\begin{tabular}{|c|c|c|c|c|c|c|c|}
\hline \multirow[b]{2}{*}{ Sorular } & \multicolumn{7}{|c|}{ Faktörler } \\
\hline & $\begin{array}{c}\text { Algilanan } \\
\text { Değer }\end{array}$ & $\begin{array}{l}\text { Değişim } \\
\text { Faydası }\end{array}$ & $\begin{array}{l}\text { Değişim } \\
\text { Maliyeti }\end{array}$ & $\begin{array}{l}\text { Değişime } \\
\text { Direnç }\end{array}$ & $\begin{array}{l}\text { Meslektaş } \\
\text { Görüşleri }\end{array}$ & Öz Yeterlik & $\begin{array}{c}\text { Örgütsel } \\
\text { Destek }\end{array}$ \\
\hline ALG1 & ,749 & & & & & & \\
\hline ALG2 & ,847 & & & & & & \\
\hline ALG3 & ,834 & & & & & & \\
\hline DEF4 & & 910 & & & & & \\
\hline DEF5 & & ,944 & & & & & \\
\hline DEF6 & & 891 & & & & & \\
\hline DEF7 & & 874 & & & & & \\
\hline DEM8 & & & 847 & & & & \\
\hline DEM9 & & &, 527 & & & & \\
\hline DEM10 & & & 853 & & & & \\
\hline DEM11 & & & 496 & & & & \\
\hline DED12 & & & & 496 & & & \\
\hline DED13 & & & & 823 & & & \\
\hline DED14 & & & & ,944 & & & \\
\hline DED15 & & & & ,925 & & & \\
\hline MEG16 & & & & & ,558 & & \\
\hline MEG17 & & & & & 628 & & \\
\hline MEG18 & & & & & 432 & & \\
\hline OZY19 & & & & & & 692 & \\
\hline OZY20 & & & & & & ,762 & \\
\hline OZY21 & & & & & & 880 & \\
\hline ORD22 & & & & & & & 881 \\
\hline ORD23 & & & & & & & 885 \\
\hline ORD24 & & & & & & & ,905 \\
\hline Cronl & 's Alpha & ,929 & & & & & \\
\hline Total Var & Explained & $\% 82,130$ & & & & & \\
\hline & & 808 & & & & & \\
\hline & & 000 & & & & & \\
\hline
\end{tabular}

Kaynak: Yazar tarafından üretilmiştir. 
Araştırmada yer alan değişkenler arası ilişki tespit edildikten sonra ölçeğin yapısal geçerliliği test edilmiştir. Bunun için açımlayıcı faktör analizi ve doğrulayıcı faktör analizi uygulanmıştır. Faktör rotasyonu için Varimax yöntemi tercih edilmiştir. Bu bağlamda, açımlayıcı faktör analizine ilişkin sonuçlar Tablo 4'te sunulmuştur.

Tablo 4'te yer alan faktör analizi sonuçları incelendiğinde, ölçeğe ait KMO değerinin ,808 ve Barlett's test sonucunun ise sig. $\mathrm{p}<0,01$ olduğu görülecektir. Bu durum, araştırmada kullanılan veri setinin örneklem büyüklüğünün yeterli olduğunu ve faktör analizi gerçekleştirmeye uygun olduğunu belirtmektedir. Ölçeğin güvenirlik katsayısı (Cronbach's Alpha) 0,929 olarak belirlenmiştir. Ayrıca araştırmada kullanılan ölçeğin 7 faktörlü bir yapı sergilediği ve açıklanan toplam varyans değerinin ise \% 82,130 olduğu tespit edilmiştir. Açımlayıcı faktör analizinde madde faktör yüklerine ilişkin sınır değer 0,40 olarak belirlenmiştir. Tablo 4 incelendiğinde ifadelerin ilgili yapı ile ilişkilerini gösteren faktör yük değerlerinin 0,40 'ın üzerinde olduğu görülecektir. Araştırma modelindeki yapılara ilişkin Cronbach's Alpha güvenirlik katsayısı ilgili modelin güvenirliğinin yüksek olduğunu göstermektedir. Bu bağlamda, araştırma modelinde yer alan yapıların genel itibari ile geçerli ve güvenilir olduğu görülmektedir.

\section{Doğrulayıcı faktör analizi}

Araştırmada gerçekleştirilen açımlayıcı faktör analizi sonuçlarına göre elde edilen faktör yapısını test etmek için doğrulayııı faktör analizi gerçekleştirilmiştir. Doğrulayıcı faktör analizi, 7 boyutlu bir yapı belirlemek için gerçekleştirilmiştir. Ayrıca ölçekte bulunan ifadelerin standardize edilmiş regresyon yüklerine ilişkin sınır değer 0,50 olarak belirlenmiştir. Bu paralelde, uygulanan analizde bir ifadenin standardize edilmiş regresyon yükünün 0,50 değerinden küçük olduğu tespit edilmiş ve DEM8 ifadesi analiz dışı bırakılarak analiz tekrar gerçekleştirilmiştir. Bu bağlamda, doğrulayıcı faktör analizi sonuçları Şekil 2'de gösterilmektedir.

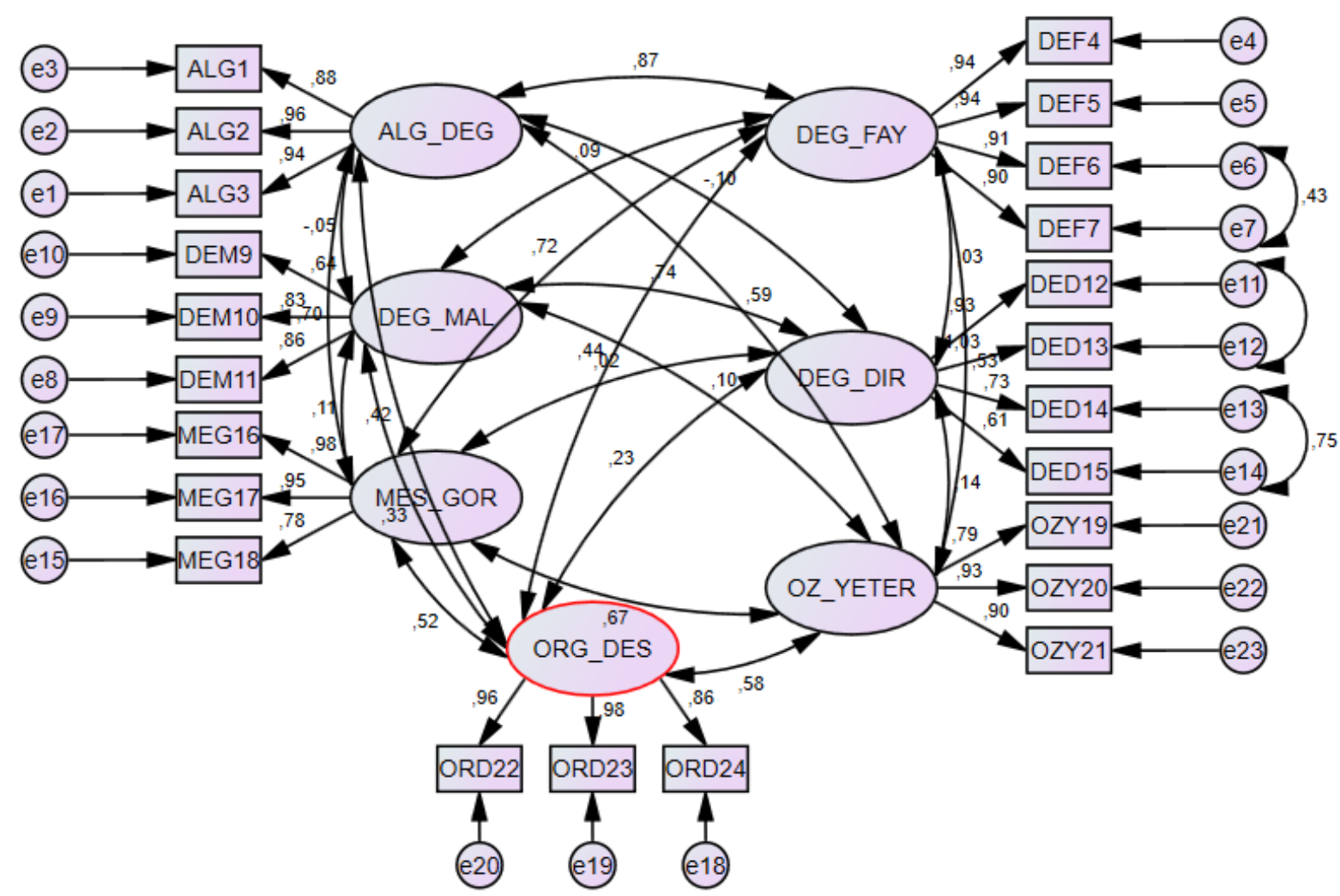

Şekil 2: Doğrulayıcı Faktör Analizi Sonuçları

ALG_DEG: Algılanan Değer, DEG_MAL: Değişim Maliyeti, DEG_FAY: Değişim Faydası, DEG_DIR: Değişime Direnç, ORG_DES: Örgütsel Destek; MES_GOR: Meslektaş Görüşleri, OZ_YETER: Öz Yeterlik

Kaynak: Yazar tarafından üretilmiştir.

CMIN/DF, RMR, CFI, IFI, TLI, RMSEA değerleri model uyumuna ilişkin referans olarak belirlenmiştir (Yaşlığlu, 2017). İndeks değerleri incelendiğinde ölçeğin bazı uyum indeksleri için gerekli değerleri sağlayamadığı belirlenmiş ve iyileştirme yapmak gayesi ile DEF6-DEF7, DED12-DED13 ve DED14DED15 ifadeleri arasında modifikasyon yapılmıştır. Modifikasyon sonrası değerlerin gerekli ölçütleri sağladığı gözlenmiştir. Bu bağlamda, araştırma modeline ait referans değerleri ve uyum indeksine ilişkin sonuçlar Tablo $5^{\prime}$ te sunulmuştur. 
Tablo 5: Modele İlişkin Uyum İndeksi Sonuçları

\begin{tabular}{|c|c|c|}
\hline İndeksler & Referans Değeri & İndeks Değerleri \\
\hline CMIN/DF & $0<\mathrm{x} 2 / \mathrm{sd} \leq 5$ & 3,590 \\
\hline GFI & $\geq, 90$ &, 923 \\
\hline RMR & $<, 10$ &, 074 \\
\hline CFI & $\geq, 92$ &, 992 \\
\hline TLI & $\geq, 92$ &, 923 \\
\hline RMSEA & $\leq, 08$ &, 065 \\
\hline
\end{tabular}

Kaynak: Yazar tarafından üretilmiştir.

\section{Yol analizi}

Doğrulayıcı faktör analizinin ardından hipotezlerin test edilmesinde yol analizleri kullanılmıştır. Eksojen değişkenlerin endojen değişken üzerinde etkilerinin yol şemasında gösterilmesi ve kompleks etki sistemlerinin sunumunun kolaylaşmasına imkan sağlaması açısından (Oktay, Akıncı ve Karaaslan, 2012), bu çalışmada yol analizi kullanılmıştır. Araştırma modeli temel alınarak gerçekleştirilen ve test edilen modele ilişkin kestirim sonuçları Şekil 3'te sunulmuştur.

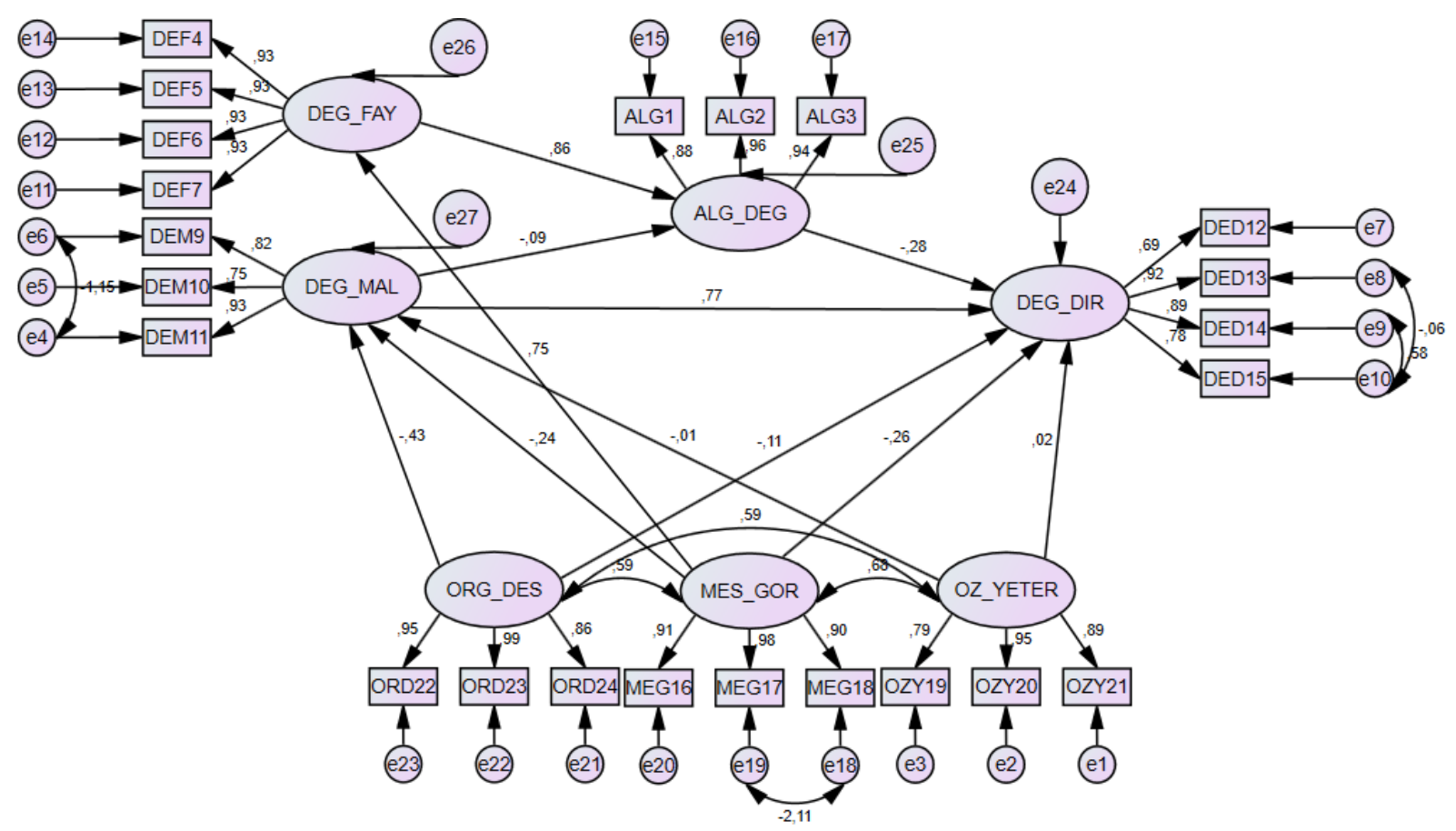

Şekil 3: Standardize Edilmiş Kestirim Sonuçlarının Model Üzerinden Gösterilmesi

ALG_DEG: Algılanan Değer, DEG_MAL: Değişim Maliyeti, DEG_FAY: Değişim Faydası, DEG_DIR: Değişime Direnç, ORG_DES: Örgütsel Destek; MES_GOR: Meslektaş Görüşleri, OZ_YETER: Öz Yeterlik

Kaynak: Yazar tarafından üretilmiştir.

İndeks değerleri incelendiğinde ölçeğin bazı uyum indeksleri için gerekli değerleri sağlayamadığı belirlenmiş ve iyileştirme yapmak gayesi ile DEM9-DEM11, DED13-DED14, DED13-DED15 ve MEG17MEG18 ifadeleri arasında modifikasyon yapılmıştır. Modifikasyon sonrası değerlerin gerekli ölçütleri sağladığı gözlenmiştir. Araştırma modeline ait referans değerleri ve uyum indeksine ilişkin sonuçlar Tablo 6'da sunulmuştur.

Tablo 6: Araştırma Modeline İlişkin Uyum İndeksi Sonuçları (Yol Analizi)

\begin{tabular}{|c|c|c|}
\hline İndeksler & Referans Değeri & Indeks Değerleri \\
\hline CMIN/DF & $0<\mathrm{x} 2 / \mathrm{sd} \leq 5$ & 3,514 \\
\hline GFI & $\geq, 90$ &, 909 \\
\hline RMR & $<, 10$ &, 095 \\
\hline CFI & $\geq, 92$ &, 945 \\
\hline TLI & $\geq, 92$ &, 936 \\
\hline RMSEA & $\leq, 08$ &, 067 \\
\hline
\end{tabular}

Kaynak: Yazar tarafından üretilmiştir.

Tablo 7' de hipotezlerin testi için gerçekleştirilen analizde modelin kestirim değerleri sunulmuştur. 
Tablo 7: Araştırma Modeline İlişkin Kestirim Sonuçları

\begin{tabular}{|c|c|c|c|c|c|c|c|}
\hline Hipotez & Endojen Değişken & Eksojen Değişken & $\begin{array}{c}\text { Standardize } \\
\text { R.Y. }\end{array}$ & S.H. & $\begin{array}{c}\text { T Terimi } \\
\text { (CR Terimi) }\end{array}$ & P & Kabul/Red \\
\hline $\mathrm{H}_{1}$ & Değişime Direnç & Algılanan Değer &,- 279 &, 071 & $-2,886$ &, 004 & Kabul \\
\hline $\mathrm{H}_{2}$ & Algilanan Değer & Değişim Maliyeti &,- 088 &, 060 & $-1,529$ &, 126 & Red \\
\hline $\mathrm{H}_{3}$ & Algılanan Değer & Değişim Faydası &, 858 &, 082 & 10,747 &, 001 & Kabul \\
\hline $\mathrm{H}_{4}$ & Değişime Direnç & Değişim Maliyeti &, 765 &, 101 & 5,826 &, 001 & Kabul \\
\hline $\mathrm{H}_{5}$ & Değisiime Direnç & Öz Yeterlik &, 023 &, 072 &, 220 &, 826 & Red \\
\hline $\mathrm{H}_{6}$ & Değişim Maliyeti & Öz Yeterlik &,- 010 &, 129 &,- 067 &, 947 & Red \\
\hline $\mathrm{H}_{7}$ & Değisisime Direnç & Örgütsel Destek &,- 108 &, 079 & $-1,068$ &, 286 & Red \\
\hline $\mathrm{H}_{8}$ & Değişim Maliyeti & Örgütsel Destek &,- 434 &, 132 & 3,375 &, 001 & Kabul \\
\hline $\mathrm{H}_{9}$ & Değisisime Direnç & Meslektaş Görüşleri &,- 259 &, 080 & 2,281 &, 023 & Kabul \\
\hline $\mathrm{H}_{10}$ & Değişim Maliyeti & Meslektaş Görüşleri &,- 241 &, 117 & $-1,869$ &, 049 & Kabul \\
\hline $\mathrm{H}_{11}$ & Değişim Faydasi & Meslektaş Görüşleri &, 753 &, 080 & 8,858 &, 001 & Kabul \\
\hline
\end{tabular}

Kaynak: Yazar tarafından üretilmiştir.

Şekil 3 ve Tablo 7 incelendiğinde, araştırma modelinde algılanan değer algısı değişime direnç faktörünü olumsuz ve anlamlı düzeyde $(-, 279, \mathrm{p}=, 004)$ etkilemekte dolayısıyla $\mathrm{H}_{1}$ desteklenmektedir. Değişim maliyeti algısının algılanan değer algısını doğrudan etkilemediği $(-, 088, p=, 126)$ ve değişim faydası algısının yine algılanan değer algısını olumlu ve anlamlı düzeyde etkilediği $(, 858, p=, 001)$ görülmektedir. Dolayısıyla $\mathrm{H}_{2}$ desteklenmemiş, $\mathrm{H}_{3}$ desteklenmiştir. Aynı zamanda değişim maliyeti algısının değişime direnç algısını olumlu ve anlamlı düzeyde $(, 765, \mathrm{p}=001)$ etkilediği belirlenmiştir. Buna göre $\mathrm{H}_{4}$ desteklenmiştir.

Şekil 3 ve Tablo 7'deki bulgulara göre; öz yeterlik faktörünün sırası ile değişime direnç ve değişim maliyeti algılarını doğrudan etkilemediği $(, 023, \mathrm{p}=, 826 ;-, 010, \mathrm{p}=, 947)$ görülmektedir. Dolayısıyla $\mathrm{H}_{5}$ ve $\mathrm{H}_{6}$ desteklenmemiştir. Örgütsel desteğin ise değişime direnç algısını doğrudan etkilemediği $(-, 108$, $\mathrm{p}=286)$ ve değişim maliyeti algısını olumsuz ve anlamlı düzeyde etkilediği $(,-434, \mathrm{p}=, 001)$ görülmektedir. Bu nedenle, $\mathrm{H}_{7}$ desteklenmemiş, $\mathrm{H}_{8}$ desteklenmiştir.

Meslektaş görüşleri algısının değişime direnç ve değişim maliyeti algılarını olumsuz ve anlamlı düzeyde $(-, 259, p=, 023,-, 241, p=, 049)$ etkilediği ve değişim faydası algısını ise olumlu ve anlamlı düzeyde $(, 753, \mathrm{p}=, 001)$ etkilediği görülmektedir. Dolayısıyla $\mathrm{H}_{9}, \mathrm{H}_{10}$ ve $\mathrm{H}_{11}$ desteklenmiştir.

\section{Tartışma ve sonuç}

Son yıllarda hızla gelişen teknoloji ile muhasebe mesleğinde veri analitiğinin yaygın olarak benimsenmesi ve entegrasyonu elzem hale gelmiştir. Ancak muhasebe meslek mensuplarını bu tür bir benimsemeyi teşvik eden veya engelleyen koşullar hakkındaki veri sınırlıdır. Bu çalışma ile muhasebe meslek mensuplarının Excel dışı veri analizi araçlarını kullanmalarına ilişkin değer algıları ve bu benimsemeyi hangi faktörlerin teşvik ettiği veya engellediği sorularını araştırarak literatüre katkıda bulunmak amaçlanmıştır. Günümüzde şirketlerin elinde çok büyük miktarda veri mevcut olduğundan, muhasebe meslek mensuplarının yeni veri analitiği teknolojisine tepkisini anlamak önem arz etmektedir.

Bu çalışmada muhasebe meslek mensuplarının yeni veri analitiği teknolojisi direncine yönelik algıları belirlenmeye çalışılmıştır. Bu doğrultuda 100 muhasebe meslek mensubundan veriler elde edilmiş ve bulgular aşağıda özetlenmiştir:

Araştırmadaki temel modelde algılanan değerin değişime direnç algısını olumsuz yönde ve anlamlı düzeyde etkilediği görülmüştür $\left(\mathrm{H}_{1}\right)$. Elde edilen bu bulgu daha önce yapılan çalışmalarda (Kim ve Kankanhalli, 2009; Schmidt, Riley ve Church, 2020; Shittu, Gambari ve Obielodan, 2016; Kim, 2011) elde edilen bulgularla örtüşmektedir. Bu bağlamda, muhasebe meslek mensuplarının yeni bir veri analitiği yazılımdan bekledikleri değerin yüksek olduğu söylenebilir.

Temel modelde, algılanan değerin değişim maliyetinden etkilenmediği ancak değişim faydasından olumlu yönde ve anlamlı düzeyde etkilendiği görülmüştür (H2, H3). Araştırma bulgularına göre değişim maliyeti, değişime direnç algısını olumlu yönde ve anlamlı düzeyde etkilemektedir (H4). Elde edilen bu bulgular daha önce yapılan çalışmalarda (Setiaputri ve Kuntara, 2019; Kim, 2011; Fan, Chen, Wu ve Fang, 2015; Tong, Tan ve Teo, 2015) elde edilen bulgular ile örtüşmektedir. Bu bağlamda, bir seçimin algılanan değerinin, o seçimin net faydasının bir fonksiyonu olduğu göz önünde bulundurulduğunda, muhasebe meslek mensuplarının algılanan değer algılarının, yeni veri analitiği aracına geçerken algıladığı faydadan başka bir ifade ile değişim faydasından etkilenmesi beklenen bir durumdur. Nitekim bir meslek mensubunun yeni veri analitiği aracına geçerken algıladığı rahatsızlık, başka bir ifade ile değişim maliyeti algılanan değeri etkilememekte ancak değişime direnç algısını etkilemektedir. 
Araştırmanın temel modelinde, muhasebe meslek mensuplarının öz yeterliklerinin değişim maliyeti ve değişime direnç algılarını etkilemediği görülmüştür $\left(\mathrm{H}_{5}, \mathrm{H}_{6}\right)$. Elde edilen bu bulgular daha önce yapılan çalışmalarda (Schmidt, Riley ve Church, 2020; Kim ve Kankanhalli, 2009) elde edilen bulgular ile örtüşmektedir. Bu bağlamda, muhasebe meslek mensuplarının düşük öz yeterlik düzeyine sahip oldukları ve yeni bir veri analitiği aracına geçiş sürecinde tehdit altında hissedecekleri ve yeni duruma hakim olmak için istenen gerekliliklerden korkma olasılıklarının yüksek olduğu söylenebilir.

Örgütsel desteğin ise değişime direnç üzerinde etkili olmadığ ancak değişim maliyeti üzerinde olumsuz yönde ve anlamlı düzeyde etkili olduğu görülmektedir $\left(\mathrm{H}_{7}, \mathrm{H}_{8}\right)$. Elde edilen bu bulgular daha önce yapılan çalışmalarda (Schmidt, Riley ve Church, 2020; Kim ve Kankanhalli, 2009) elde edilen bulgular ile örtüşmektedir. Bu bağlamda, muhasebe meslek mensuplarının yeni veri analitiği aracına geçiş sürecinde algıladığı rahatsızlığın örgütsel destek ile azaltılmasını bekledikleri söylenebilir. Nitekim muhasebe meslek mensuplarının öz yeterliklerinin düşük seviyede olduğu dolayısıyla geçiş sürecinde desteğe ihtiyaç duydukları söylenebilir.

Temel modelde meslektaş görüşlerinin; değişime direnç ve değişim maliyeti algıları üzerinde olumsuz yönde ve anlamlı düzeyde etkili olduğu $\left(\mathrm{H}_{9}, \mathrm{H}_{10}\right)$, değişim faydası algısı üzerinde ise olumlu yönde ve anlamlı düzeyde etkili olduğu görülmektedir $\left(\mathrm{H}_{11}\right)$. Elde edilen bu bulgular daha önce yapılan çalışmalarda (Venkatesh ve Davis, 2000; William Lewis ve Sambamurthy, 2003; Schmidt, Riley ve Church, 2020; Kim ve Kankanhalli, 2009) elde edilen bulgular ile örtüşmektedir.

Araştırma bulgularına göre, muhasebe meslek mensuplarının yeni veri analitiği teknolojisine ilişkin algılanan değerlerinin değişim faydasının bir fonksiyonu olarak gördüklerini göstermektedir. Ancak katılımcılar, değişim maliyetinin algılanan değer üzerinde etkisiz olduğunu düşünmektedirler. Bununla birlikte değişim maliyetlerinin, yeni bir veri analitiği teknolojisine geçişe ilişkin direnç üzerinde güçlü ve olumsuz doğrudan etkisi vardır. Araştırma bulgularında, meslektaş görüşüne ilişkin tespitler önem arz etmektedir. Buna göre, meslektaş görüşleri değişim faydası algısını önemli ölçüde ve pozitif olarak etkilemekte ve değişime direnci azaltmaktadır.

İşletmeler, finansal verilerin sağlanması yoluyla verimli ve etkili bir işletme modelini sürdürmeyi amaçlarlar. Büyük Veri'nin yükselişi ve yeni veri analitiği teknolojileri ile bazı organizasyonel yapılar bir dönüşüme uğrayacaktır. Toplama ve işleme aşamaları boyunca veri bütünlüğünün kilit rolünü anlamak, iş modelini daha ayrıntılı bir bilgi anlayışı temelinde tasarlamak, veri analizi için yeni teknolojilerin daha iyi kullanılmasını sağlamak, maliyet yönetiminin artan önemi ve diş kaynak kullanımı ve bulut tabanlı olanaklar, muhasebe meslek mensupları için bir değişimi zorunlu kilmaktadir.

Aynı zamanda farklı bölgeler ve illerde faaliyet gösteren muhasebe meslek mensuplarına araştırmada kullanılan ölçek uygulanıp farklılıklar belirlenebilir. Bu tür çalışmaların hayata geçirilmesi, muhasebe meslek mensuplarının yeni veri analitiği teknolojisine geçişe direnç göstermesine yol açan faktörlerin belirlenmesine ve muhasebe meslek mensuplarının çağın gerekliliklerine uygun araçlar kullanmasına yardımcı olacaktır.

Gelecekte gerçekleştirilecek çalışmalar için muhasebe meslek mensuplarının maruz kaldığ1 geçiş maliyetlerinin azaltılmasına ilişkin incelemeler gerçekleştirilmesi önerilmektedir. Bununla kastedilen yalnızca zaman ve eğitim gibi tanımlanabilir kaynakları optimize etmek değil, aynı zamanda muhasebe meslek mensuplarının kişilik özellikleri de göz önünde bulundurulmasıdır.

\section{Araştırmanın sınırları ve kısıtları}

Araştırma örneğinin Aksaray şehir merkezinde aktif olarak faaliyet gösteren SMMM'ler ile sınırlandırılması, bu araştırmanın kısıtını oluşturmaktadır.

\section{Hakem Değerlendirmesi / Peer-review:}

Dış bağımsız

Externally peer-reviewed

\section{Çıkar Çatışması / Conflict of interests:}

Yazar(lar) çıkar çatışması bildirmemiştir.

The author(s) has (have) no conflict of interest to declare. 


\section{Finansal Destek / Grant Support:}

Yazar(lar) bu çalışma için finansal destek almadı̆̆ını beyan etmiştir.

The author(s) declared that this study has received no financial support.

\section{Etik Kurul Onayı / Ethics Committee Approval:}

$\mathrm{Bu}$ çalışma için etik kurul onayı, Aksaray Üniversitesi, İnsan Araştırmaları Etik Kurulu'ndan 21/06/2021 tarihli 2021/05-10 sayılı karar ile alınmıştır.

Ethics committee approval was received for this study from Aksaray University, Human Research Ethics Committee on 21/06/2021 and 2021/05-10 document number.

\section{Kaynakça / References}

Agyekum, A. A., \& Singh, R. P. (2018). How Technology is Changing Accounting Processes: Institutional Theory and Legitimacy Theory Perspective. Journal of Accounting and Finance, 18(7), 11-23.

Ajzen, I. (2002). Perceived Behavioral Control, Self-Efficacy, Locus of Control, and the Theory of Planned Behaviour. Journal of Applied Social Psychology (32), 665-683.

Akdoğan, N., \& Akdoğan, M. U. (2018). Büyük veri- Bilişim Teknolojisindeki Gelişmelerin Muhasebe Uygulamarına ve Muhasebe Mesleğine Etkisi. Muhasebe ve Denetime Bakış, 18(55), 1-14.

Aktan, E. (2018). Büyuk Veri: Uygulama Alanları, Analitiği ve Güvenlik Boyutu. Bilgi Yönetimi Dergisi, $1(1), 1-22$.

Ballou, B., Heitger, D. L., \& Stoel, D. (2018). Data-Driven Decision-Making and its Impact on Accounting Undergraduate Curriculum. Journal of Accounting Education (44), 14-24.

Beder, N. (2021). Muhasebe Meslek Mensuplarının Yeni Dünya ile İmtihanı. Anadolu Üniversitesi Sosyal Bilimler Dergisi, 21(1), 163-184.

Cainas, J. M., Tietz, W. M., \& Miller-Nobles, T. (2021). KAT Insurance: Data Analytics Cases for Introductory Accounting Using Excel, Power BI, and/or Tableau. Journal of Emerging Technologies in Accounting, 18(1), 77-85.

Cao, M., Chychyla, R., \& Stewart, T. (2015). Big Data Analytics in Financial Statement Audits. Accounting Horizons, 29(2), 423-429.

Compeau, D., Higgins, C. A., \& Huff, S. (1999). Social Cognitive Theory and Individual Reactions to Computing Technology: A Longitudinal Study. MIS Quarterly, 23(2), 145-158.

Dursun, G. D., Ektik, D., \& Tutcu, B. (2019). Mesleğin Dijitalleşmesi: Muhasebe 4.0. Avrasya Sosyal ve Ekonomi Araştırmaları Dergisi, 6(6), 263-271.

Dzuranin, A. C., Jones, J. R., \& Olvera, R. M. (2018). Infusing Data Analytics into the Accounting Curriculum: A Framework and Insights from Faculty. Journal of Accounting Education(43), 24-39.

Eisenberger, R., Huntington, R., Hutchison, S., \& Sowa, D. (1986). Perceived Organizational Support. Journal of Applied Psychology, 71(3), 500-507.

Fan, Y.-W., Chen, C.-D., Wu, C.-C., \& Fang, Y.-H. (2015). The Effect of Status Quo Bias on Cloud System Adoption. Journal of Computer Information Systems, 55(3), 55-64.

Frey, C. B., \& Osborne, M. (2013). The Future of Employment. Oxford: Oxford Martin Programme on Technology and Employment.

Hutchison, S. (1997). A Path Model of Perceived Organizational Support. Journal of Social Behavior and Personality, 12(1), 159-174.

Kılıç, B. İ. (2019). Muhasebe, Finans ve Denetim Alanlarında Ön Plana Çıkan Büyük Veri Analiz Teknikleri ve Teknolojileri. Uluslararası Yönetim, Ekonomi ve Politika Kongresi, (s. 498-511). İstanbul.

Kahneman, D. (2015). Hızlı ve Yavaş Düşünme. İstanbul: Varlık Yayınları.

Kahneman, D., \& Tversky, A. (1979). Prospect Theory: An Analysis of Decision Under Risk. Econometrica, 47(2), 263-292. 
Kim, H.-W. (2011). The Effects of Switching Costs on User Resistance to Enterprise Systems Implementation. IEEE Transactions on Engineering Management, 58(3), 471-482.

Kim, H.-W., \& Kankanhalli, A. (2009). Investigating User Resistance to Information Systems Implementation: A Status Quo Bias Perspective. MIS Quarterly, 33(3), 567-582.

Oktay, E., Akıncı, M. M., \& Karaaslan, A. (2012). Yol Analizi Yardımıyla Dersler Arasındaki Etkileşimin Araştırılması: Atatürk Üniversitesi İktisadi ve İdari Bilimler Fakültesi İşletme Bölümünde Okutulan Dersler Üzerine Bir Uygulama. Atatürk Üniversitesi İktisadi ve İdari Bilimler Dergisi, 26(3-4), 67-83.

Özer, G., Özcan, M., \& Aktaş, S. (2010). Muhasebecilerin Bilgi Teknolojisi Kullanımının Teknoloji Kabul Modeli (TKM) ile İncelenmesi. Journal of Yasar University, 5(19), 3278 - 3293.

Pardo del Val, M., \& Martinez Fuentes, C. (2003). Resistance to Change: A Literature Review and Empirical Study. Management Decision, 41(2), 148-155.

Pehlivanlı, E. A. (2020). Öncülleri ve Ardılları ile İşkoliklik. A. Yalçın (Ed.), Yönetim Bilimleri (s. 67-82). Ankara: Akademisyen Kitabevi.

Rajaraman, V. (2016). Big Data Analytics. Resonance(Ağustos), 695-716.

Richins, G., Stapleton, A., Stratopoulos, T. C., \& Wong, C. (2017). Big Data Analytics: Opportunity or Threat for the Accounting Profession? Journal of Information Systems, 31(3), 63-79.

Saunders, M., Lewis, P., \& Thornhill, A. (2007). Research Methods for Business Students. Essex: Pearson Education.

Schmidt, P. J., Church, K. S., \& Riley, J. (2020). Clinging to Excel as a Security Blanket: Investigating Accountants' Resistance to Emerging Data Analytics Technology. Journal of Emerging Technologies $n$ Accounting, 17(1), 33-39.

Schmidt, P. J., Riley, J., \& Church, K. S. (2020). Investigating Accountants' Resistance to Move beyond Excel and Adopt New Data Analytics Technology. Accounting Horizons, 34(4), 165-180.

Schneider, G. P., Dai, J., Janvrin, D. J., Ajayi, K., \& Raschke, R. L. (2015). Infer, Predict, and Assure: Accounting Opportunities in Data Analytics. Accounting Horizons, 29(3), 719-742.

Setiaputri, S., \& Kuntara, A. D. (2019). The Role of Perceived Value, Switching Cost, and Self-Efficacy for Change Toward User Resistance of Parish Accounting Software. International Conference on Rural Development and Entrepreneurship 2019: Enhancing Small Business and Rural Development Toward Industrial Revolution 4.0, (s. 1083-1094).

Shittu, A. T., Gambari, A. I., \& Obielodan, O. O. (2016). Resistance to Change, Perceived Value, Self Efficacy and Attitude Towards Use of Information Technology for Teaching among Primary School Teachers in Ilorin, Nigeria. Benue State University Journal of Education, 16(1), 270-273.

Tong, Y., Tan, S. S.-L., \& Teo, H.-H. (2015). The Road to Early Success: Impact of System Use in the Swift Response Phase. Information Systems Research, 26(2), 418-436.

Tsai, C.-W., Lai, C.-F., Chao, H.-C., \& Vasilakos, A. V. (2015). Big Data Analytics: A Survey. Journal of Big Data, 2(21), 1-32.

Vasarhelyi, M. A., Kogan, A., \& Tuttle, B. M. (2015). Big Data in Accounting: An Overview. Accounting Horizons, 29(2), 381-396.

Venkatesh, V., \& Davis, F. D. (2000). A Theoretical Extension of the Technology Acceptance Model: Four Longitudinal Field Studies. Management Science, 46(2), 186-204.

Warren Jr., J. D., Moffitt, K. C., \& Byrnes, P. (2015). How Big Data Will Change Accounting. Accounting Horizons, 29(2), 397-407.

William Lewis, R. A., \& Sambamurthy, V. (2003). Sources of Influence on Beliefs about Information Technology Use: An Empirical Study of Knowledge Workers. MIS Quarterly, 27(4), 657-678.

Yaşlıŏlu, M. M. (2017). Sosyal Bilimlerde Faktör Analizi ve Geçerlilik: Keş̧fedici ve Dogrulayıcı Faktör Analizlerinin Kullanılması. Istanbul University Journal of the School of Business(46), 74-85.

Yardımcıŏ̆lu, M., Karahan, M., \& Yörük, A. (2019). Dijitalleşme Işı̆̆ında Muhasebe Mesleğinin Geleceği. Muhasebe Enstitüsü Dergisi(61), 35-46.

Zakir, J., Seymour, T., \& Berg, K. (2015). Big Data Analytics. Issues in Information Systems, 16(2), 81-90. 